\title{
The Quran: Key Word Collocations
}

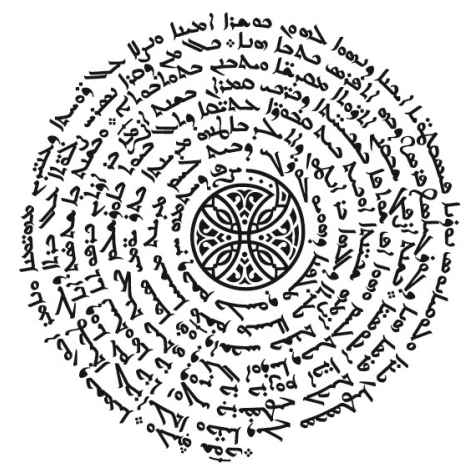




\section{Gorgias Islamic Studies}

15

Gorgias Islamic Studies spans a wide range of subject areas, seeking to understand Islam as a complete cultural and religious unity. This series draws together political, socio-cultural, textual, and historical approaches from across disciplines. Containing monographs, edited collections of essays, and primary source texts in translation, this series seeks to present a comprehensive, critical, and constructive picture of this centuries- and continent-spanning religion. 


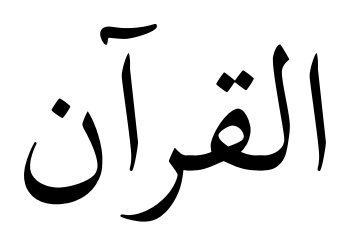

\title{
The Quran
}

\section{Key Word Collocations}

Adjectives, Nouns, Proper Nouns and Verbs

\author{
Volume 10 \\ 'B' - 'YY / عبأ - عيي
}

Elie Wardini

Gporgias

2021 
Gorgias Press LLC, 954 River Road, Piscataway, NJ, 08854, USA

www.gorgiaspress.com

2021 Copyright (C) by Gorgias Press LLC

All rights reserved under International and Pan-American Copyright Conventions. No part of this publication may be reproduced, stored in a retrieval system or transmitted in any form or by any means, electronic, mechanical, photocopying, recording, scanning or otherwise without the prior written permission of Gorgias Press LLC.

2021

$$
\checkmark
$$

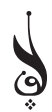

ISBN 978-1-4632-4315-9

ISSN 2637-3998

\section{Library of Congress Cataloging-in-Publication Data}

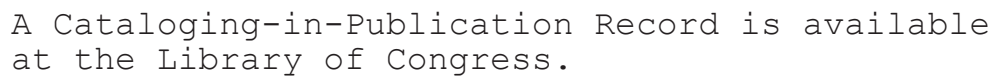

Printed in the United States of America 